tion of medical and nursing care, and nutritional intervention, which have improved the survival rate in this most challenging group of patients from $60 \%$ to $88 \%$. This has been achieved with good quality of life despite a high perioperative morbidity and the greater technical difficulties related to the small size of the patient.

We acknowledge the dedication of the nursing staff at the Children's Hospital, and the Queen Elizabeth Hospital, whose skill brought these children back to health. We thank Dr Gill Harris, clinical psychologist, for her advice.

1 Whitington PF, Balistreri W. Liver transplantation in pediatrics: indications, contraindications, and pretransplant management. $f$ Pediatrics 1991;118: 169-77.

2 Esquivel C, Koneru B, Karrer F, Todo S, Iwatsuki S, Gordon R, et al. Liver transplantation before 1 year of age. $\mathcal{F}$ Pediatr 1987;110:545-8.

3 Chiyende J, Mowat AP. Liver transplantation. Arch Dis Child 1992;67:1124-7.

4 Otte JB, deVille de Goyet J, Sokal E, Alberti D, Moulin D, de Hemptinne B, et al. Size reduction of the donor liver is a safe way to alleviate the shortage of size matched organs in pediatric liver transplantation. Ann Surg 1990;211: $146-57$.

5 Ryckman FC, Flake AW, Fisher RA, Tchervenkov JI, Pedersen SM Balistreri WF, et al. Segmental orthotopic hepatic transplantation as a mean to improve patient survival and waiting-list mortality. $f$ Pediatr Surg 1991;26:422-7.

6 Badger II, Czerniak A, Beath S, Tisone G, Deakin M, Sherlock DJ, et al. Hepatic transplantation in children using reduced size allografts. Br $\mathcal{F}$ Surg 1992;79:47-9.

7 Kalayoglu M, Stratta RJ, Sollinger HW, Hoffman RM, D'Alessandro AM, Pirsch JD, et al. Liver transplantation in infants and children. $f$ Pediatr Surg 1989;24:70-6.

8 Houssin D, Soubrane O, Boillot O, Dousset B, Ozier Y, Devictor D, et al. Orthotopic liver transplantation with reduced size graft: an ideal compromise in pediatrics? Surgery 1992;111:532-42.

9 Salt A, Noble-Jamieson G, Barnes ND, Mowat AP, Rolles K, Jamieson N, et al. Liver transplantation in 100 children: Cambridge and King's College Hospital series. BMf 1992;304:416-21.

10 Sokal EM, Veyckemans F, de Ville de Goyet J, Moulin D, Van Hoorebeeck N Alberti $\mathrm{D}$, et al. Liver transplants in children less than 1 year of age. fPediatr 1990;117:205-10
11 Lynch SV, Akiyama T, Ong TH, Pillay SP, Balderson GA, Matsunami H, et al. Transplantation in children with biliary atresia. Transplant Proc 1992;24:186-8.

12 Sann L, Durand M, Picard J, Lasney, Bethenod M. Arm fat and muscle areas in infancy. Arch dis Child 1988;63:256-60.

13 Frisancho AR. New norms of upper limb fat and muscle areas for assessment of nutritional status. Am f Clin Nutr 1981;34:2540-5.

14 Jordan MD. The CDC anthropometric software package. Version 3. Atlanta Centers for Disease Control, 1987.

15 Smith DE, Booth IW. Nutritional assessment of children: guidelines on collecting and interpreting anthropometric data. f Human Nutr Diet. 1989;2:217-24.

16 Griffiths Mental Development Scales. High Wycombe. The Test Agency, 1986.

17 Pocock SJ, ed Clinical trials: a practical approach. Chichester; John Wiley, 1983:222-4.

18 Morgan GE, Mikhail MS. Pediatric anesthesia. In: Morgan GE, Mikhail MS, eds. Clinical anesthesiology. London: Prentice Hall International, 1992: 630-6.

19 Kaufman SS, Murray ND, Wood RP, Shaw BW, Vanderhoef JA. Nutritional support for the infant with extrahepatic biliary atresia. $f$ Pediatr 1987;110 679-86.

20 Brooke OG. Energy needs in infancy. In: Foman SJ, Heird WC, eds. Energy and protein needs during infancy. London: Academic Press, 1986:3-17.

1 Moukarzel AA, Najm I, Vargas J, McDiarmid SV, Busuttil RW, Ament ME Effect of nutritional status on outcome of orthotopic liver transplantation in pediatric patients. Transplant Proc 1990;22:1560-3.

22 Harris G, Booth IW. Feeding problems and eating disorders in children and adolescents. In: Cooper PJ, Stein A, eds. Monographs in clinical pediatrics. Vols. Reading: Harwood Academic Publishers, 1992:61-84.

23 Miyawaki T, Moriya N, Nagaoki T, Taniguchi N. Maturation of B-cell differentiation ability and $T$-cell regulatory function in infancy and childhood. Immunol Rev 1981;57:61-87.

24 Buckels JAC, Tisone G, Gunsen BK, McMaster P. Low haematocrit reduces hepatic artery thromobosis after liver transplantation. Transplant Proc 1989;21:2460-1.

25 Chin SE, Shepherd RW, Cleghorn GJ, Patrick MK, Javorsky G, Frangoulis E, et al. Survival, growth and quality of life in children after orthotopic liver transplantation: a 5 year experience. $\mathcal{F}$ Paediatr Child Health 1991;27:380-5.

26 Stewart SM, Uauy R, Waller DA, Kennard BD, Benser M, Andrews WS Mental and motor development, social competence, and growth one year after successful pediatric liver transplantation. $\mathcal{F}$ Pediatr 1989;114:574-81.

27 Malatack JJ, Schaid DJ, Urbach AH, Gartner JC, Zitelli BJ, Rockette H, et al. Choosing a pediatric recipient for orthotopic liver transplantation. 9 Pediat 1987;111:479-89.

(Accepted 12 August 1993)

\title{
Radioiodine treatment of multinodular non-toxic goitre
}

\author{
Birte Nygaard, Laszlo Hegedüs, Morten Gervil, Henrik Hjalgrim, Peter Søe-Jensen, \\ Jens Mølholm Hansen
}

\section{Departments of Internal \\ Medicine and \\ Endocrinology and \\ Ultrasound, Herlev \\ University Hospital, \\ DK 2730 Herlev, Denmark \\ Birte Nygaard, registrar \\ Morten Gervil, registrar \\ Henrik Hjalgrim, registrar \\ Peter Søe-Jensen, medical student \\ Jens Mølholm Hansen, \\ consultant physician}

\section{Department of Internal \\ Medicine and \\ Endocrinology, Odense \\ University Hospital, \\ DK 5000 Odense C, \\ Denmark \\ Laszlo Hegedüs, consultant}

physician

Correspondence and reprint requests to:

Dr Laszlo Hegedüs,

Department of Internal

Medicine and

Endocrinology $M$,

Odense University Hospital,

DK-5000 Odense C,

Denmark.

BMf 1993;307:828-32

\section{Abstract}

Objective-To investigate the long term effect of radioactive iodine on thyroid function and size in patients with non-toxic multinodular goitre.

Design-Consecutive patients with multinodular non-toxic goitre selected for radioactive iodine treatment and followed for a minimum of 12 months (median 48 months) after an intended dose of 3. $7 \mathrm{MBq} / \mathrm{g}$ thyroid tissue corrected to a $100 \%$ uptake of iodine-131 in 24 hours.

Patients -69 patients with a growing multinodular non-toxic goitre causing local compression symptoms or cosmetic inconveniences. The treatment was chosen because of a high operative risk, previous thyroidectomy, or refusal to be operated on.

Main outcome measurements-Standard thyroid function variables and ultrasonically determined thyroid volume before treatment as well as $1,2,3,6$, and 12 months after treatment and then once a year.

Results-56 patients were treated with a single dose of ${ }^{131} I, 12$ with two doses, and one with four doses. In 45 patients treated with one dose and remaining euthyroid the median thyroid volume was reduced from 73 (interquartile range 50-106) $\mathrm{ml}$ to 29 (23-48) $\mathrm{ml}$ at 24 months in the 39 patients in whom this was measured during follow up. The median reduction was $40 \quad(22-48) \mathrm{ml}(60 \%$ reduction, $\mathbf{p}<0.0001$ ), half of which occurred within three months. Patients treated with two doses as well as those developing hypothyroidism and hyperthyroidism had a significant reduction in thyroid volume. Eleven patients developed hypothyroidism (cumulative five year risk $22 \%, 95 \%$ confidence interval $4 \cdot 8 \%$ to $38 \cdot 4 \%$ ). Side effects were few: three cases of hyperthyroidism and two cases of radiation thyroiditis. Only one patient was dissatisfied with the result; she was referred for operation six months after treatment.

Conclusions-A substantial reduction in thyroid volume accompanied by a low incidence of hypothyroidism and few side effects makes the use of radioactive iodine an attractive alternative to surgery in selected cases of non-toxic multinodular goitre.

\section{Introduction}

The yearly growth rate of non-toxic multinodular goitres has been estimated at $10-20 \% .^{1}$ Suppressive treatment with thyroxine or triiodothyronine reduces the thyroid volume in diffuse non-toxic goitre by up to $30 \%,{ }^{2}$ but it is disputed whether such an effect can be achieved in multinodular glands. ${ }^{134}$ The growing nodular non-toxic goitre is traditionally treated by subtotal thyroidectomy.

At least $10 \%$ of patients have a recurrence after subtotal thyroidectomy for non-toxic multinodular goitre. ${ }^{56}$ In these patients, as well as in others with a high surgical risk, a non-operative reduction in thyroid size would be desirable. Treatment of hyperthyroidism with radioactive iodine $\left({ }^{131} \mathrm{I}\right)$ is well accepted and usually results in a substantial decrease in the size of the thyroid. ${ }^{78}$ The possibility of ${ }^{131} I$ treatment of non- 
toxic multinodular goitre is less accepted, but recently we found a $41 \%$ reduction in ultrasonically determined thyroid volume within one year of treating such patients with ${ }^{131} \mathrm{I} .{ }^{9}$ The present study investigated the long term consequences of ${ }^{131} I$ treatment on thyroid function and thyroid volume in a large group of patients with non-toxic multinodular goitre to clarify the future role of this treatment.

\section{Patients and methods}

Sixty nine patients (62 women) with multinodular non-toxic goitre selected for radioactive iodine treatment during the period 1981-91 were followed for a minimum of 12 months. Median age was 57 (range 3083) years and all patients had a multinodular goitre on technetium-99m thyroid scanning. The indication for treatment was a growing multinodular goitre, assessed clinically or by ultrasonography on at least two visits, causing either local compression symptoms or-in a few cases-cosmetic inconvenience. This treatment was chosen owing to a high operative risk (cardiac or pulmonary disease, or both), previous thyroidectomy, or refusal to be operated on. None of our patients was pregnant or contemplated further pregnancies at the time of selection for treatment. Of the 13 patients who had had a thyroidectomy, nine had been operated on once, three twice, and one three times.

We intended to give ${ }^{131} \mathrm{I}$ at a dose of $3.7 \mathrm{MBq}$ (100 $\mu \mathrm{Ci})$ per gram of total thyroid mass corrected to a $100 \%$ uptake of ${ }^{131} \mathrm{I}$ in 24 hours. In some cases-for example, a goitre of $200 \mathrm{~g}$ with an ${ }^{131} \mathrm{I}$ uptake of $20 \%$ in 24 hours - this would have meant giving large (3700 $\mathrm{MBq}(100 \mathrm{mCi}))$ single doses. For several reasons, including local irradiation protocol, a maximum single dose of $1110 \mathrm{MBq}$ ( $30 \mathrm{mCi}$ ) was chosen. Consequently, 18 of the largest glands were given a lower dose $(<3.7 \mathrm{MBq} / \mathrm{g}$ thyroid tissue) than intended.

Pretreatment, a ${ }^{99 \mathrm{~m}} \mathrm{Tc}$ thyroid scan, was performed in all patients with a gamma camera, using $3 \mathrm{mCi}{ }^{99 m} \mathrm{Tc}-$ pertechnetate. Serum concentrations of thyroxine (normal range 59-129 $\mathrm{nmol} / \mathrm{l}$ ) and triiodothyronine (normal range $1 \cdot 0-2.5 \mathrm{nmol} / \mathrm{l}$ ) and a triiodothyronine resin uptake test (normal range $0 \cdot 80-1 \cdot 25$ arbitrary units) were determined by in house methods (assay variation was $6 \%, 10 \%$, and $5 \%$ respectively. Free thyroxine index and free triiodothyronine index were calculated as the total hormone concentration times the resin uptake and given in arbitrary units. Serum concentration of thyroid stimulating hormone was determined, up to 1986 , by a previously described radioimmunoassay..$^{10}$ From 1986 to 1989 we used an immunoradiometric assay (Boots-Celltech, England) with an intra-assay coefficient of variation of $2 \cdot 3-4 \cdot 7 \%$ and a detection limit of $0.03 \mathrm{mU} / \mathrm{l}$. From 1989 we used the Delfia hTSH assay (Wallac, Turku, Finland), which has an intra-assay coefficient of variation of $3 \cdot 7-5 \cdot 4 \%$ and a detection limit of $0.03 \mathrm{mU} /$.

Hyperthyroidism was defined as a subnormal serum concentration of thyroid stimulating hormone with a concomitant increase in serum concentration of thyroxine or triiodothyronine, or both. Hypothyroidism was defined as a raised serum thyroid stimulating hormone concentration concomitant with a decrease in free thyroxine index. Patients with raised serum thyroid stimulating hormone concentrations but normal free thyroxine index were classified as having compensated hypothyroidism (seven of 11 hypothyroid patients). These patients were treated with levothyroxine for subjective complaints compatible with hypothyroidism (mainly weight gain) and increasing serum thyroid stimulating hormone concentrations. In the statistical analysis and in the results section these patients were classed as hypothyroid.
Ultrasonic scanning and calculation of total thyroid volume (normal range $9 \cdot 6-27 \cdot 6 \mathrm{ml}$ ) were performed as previously described ${ }^{10}$ with a compound scanner (type 1846, Bruel and Kjaer, Naerum, Denmark). The method in essence comprises obtaining transverse scans of the thyroid with $5 \mathrm{~mm}$ intervals from caudal to cranial with the patient supine with hyperextension of the neck. The outline of the gland on the screen of the monitor can be digitised with a light pen connected to a computer for calculation of the surface of one outline and the volume between two successive transverse scans. The sum of all partial volumes equals the total thyroid volume. The average inaccuracy of this method is $7 \%$ without any consistent overestimation or underestimation. ${ }^{10}$ The mean interobserver variation is $5 \%{ }^{10}$ and the mean intraobserver variation is $5 \% .^{11}$

Thyroid function variables and the size of the thyroid on ultrasonography were determined before treatment as well as one, two, three, six, and 12 months after treatment and thereafter once every year. Informed consent was obtained from all patients.

Ten subjects (all women) with a median age of 60 (range 46-83) years and an initial thyroid volume of 45 $(25-161) \mathrm{ml}$ need special mention. All were treated with one dose of ${ }^{131} \mathrm{I}$. Follow up data on thyroid volume were not available for these women, but several developed hypothyroidism. So that the prevalence of hypothyroidism would not be underestimated these patients were included. Six of the 10 patients were euthyroid when lost to follow up. Of these six, two patients died of unrelated reasons at age 80 and 85 , three years and one year, respectively, after ${ }^{131}$ I treatment. One patient emigrated, and two were referred back to their private practitioners after 12 and 24 months. One patient was dissatisfied with the effect of treatment and was referred for operation six months after treatment; at this time the initial thyroid volume of $30 \mathrm{ml}$ was unchanged and she was euthyroid. The remaining four of the 10 patients were treated with levothyroxine-three because of compensated hypothyroidism-within 12 months of treatment and referred back to their private practitioner.

\section{STATISTICAL EVALUATION}

When calculating the incidence of hypothyroidism we used life table analysis. Longitudinal changes in thyroid gland volume were analysed by the Page test for trend.12 Because of the lack of volume estimations from different patients at different times, one value obtained before and two values obtained after ${ }^{131} \mathrm{I}$ treatment were used for this test. The values after treatment were the average of the results from six and 12 months, and 24 and 36 months. When both values were missing the patient was excluded from the Page test evaluation, and when only one value was available this value was used. Significance level was chosen at $\mathrm{p}<0.05$.

\section{Results}

Median initial thyroid volume in the 69 patients was 74 (range 21-296). All patients were clinically and biochemically euthyroid, but in 21 patients serum thyroid stimulating hormone concentrations were subnormal $(<0.4 \mathrm{mU} / \mathrm{l})$.

Fifty six patients $(51$ women) were treated with a single ${ }^{131} \mathrm{I}$ dose and were followed for a median of 60 (12-120) months. Median ${ }^{131}$ I dose was 555 (148-1110) MBq. Ten of these patients received a lower dose than intended. Forty five patients remained euthyroid during the follow up period. In the 39 patients in whom it was measured, median thyroid volume decreased gradually from 73 (interquartile range 50-106) to $29(23-48) \mathrm{ml}$ after 24 months $(60 \%$ reduction, $\mathrm{p}<0.0001)$. Thereafter no significant alterations in 


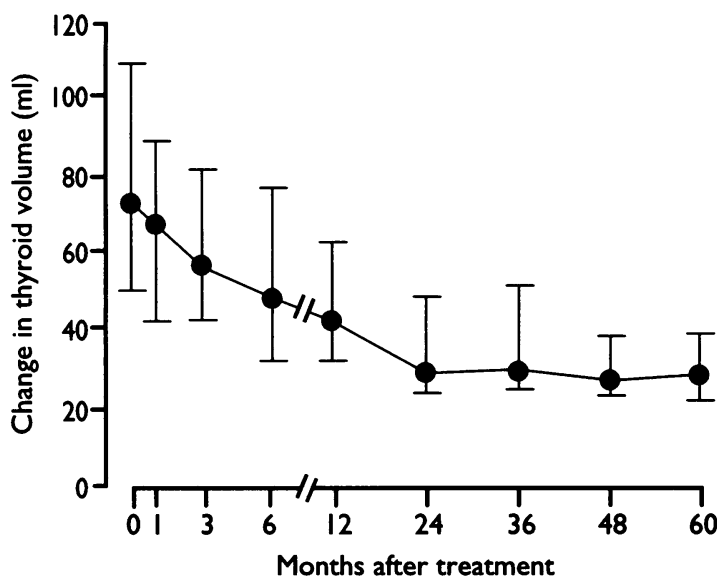

FIG 1-Median changes in thyroid volume alterations after iodine-131 treatment in 39 patients with non-toxic multinodular goitre who remained euthyroid after a single dose. Bars are quartiles

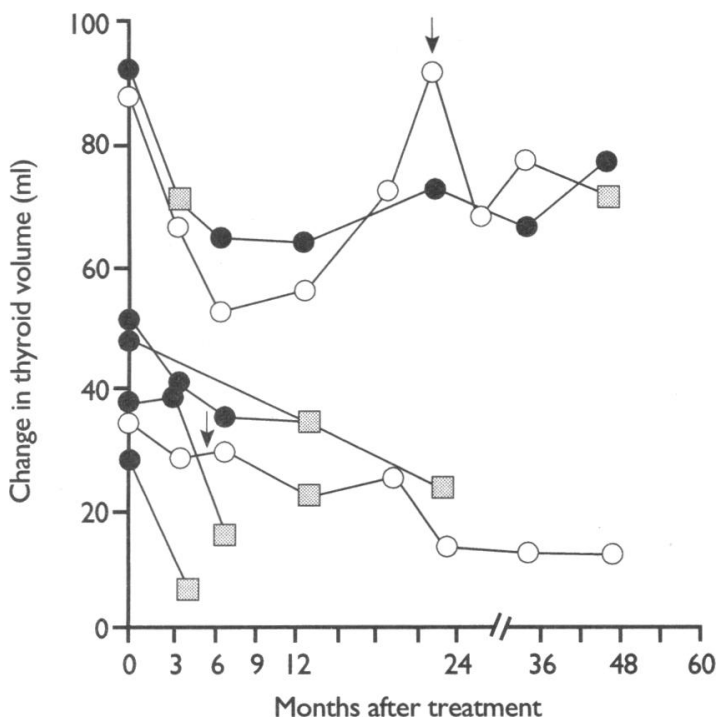

FIG 2 - Changes in thyroid volume in five patients $(\bullet-)$ developing hypothyroidism after one dose of iodine-131 and two patients developing hypothyroidism after two doses given for non-toxic multinodular goitre $(\mathrm{O}-\mathrm{O})$. Arrow indicates time of second dose; box indicates diagnosis of hypothyroidism or thyroxine substitution (or both)

thyroid volume occurred (fig 1). Within this period thyroid size was normalised in 19 of the 39 patients (49\%).

Nine patients developed hypothyroidism after a median of six (range 3-36) months. Median ${ }^{131} \mathrm{I}$ dose was $474 \mathrm{MBq}(296-1110)$ and thyroid volume was reduced from a median of $48(28-93) \mathrm{ml}$ to $15(8-71) \mathrm{ml}$ $(69 \%$ decrease, $p<0.05)$ in the five patients in whom it was measured (fig 2). Five of these patients had compensated hypothyroidism with normal free thyroxine index and raised serum thyroid stimulating hormone concentrations $(7,12,16,27$, and $29 \mathrm{mU} / \mathrm{l})$.

Two patients developed hyperthyroidism three months after ${ }^{131} I$ treatment. Both were treated with antithyroid drugs for several months and thereafter remained euthyroid. Figure 3 shows thyroid volumes. Neither patient had a family history of Graves' disease or other thyroid disorders, but antibodies to thyroid stimulating hormone receptor and thyroid peroxidase were not measured, so evidence for or against Graves' disease cannot be provided.

Twelve patients were treated with a second dose of ${ }^{131}$ I, mainly to reduce thyroid volume further. They were followed for a median of 48 (12-72) months from the first treatment, with a median of $12(2-24)$ months between the two treatments. Median initial ${ }^{131} I$ dose was 611 (252-925) MBq, and the median second dose was $740(222-925) \mathrm{MBq}$. Seven of these patients received a lower initial dose than intended. Nine patients remained euthyroid during the follow up period. In these patients the initial ${ }^{131} I$ dose reduced thyroid volume from 90 (34-296) $\mathrm{ml}$ to $84(25-223) \mathrm{m}$ $(\mathrm{p}<0.05)$ and the second dose reduced thyroid volume from $84(25-223) \mathrm{ml}$ to $69(11-130) \mathrm{ml}(\mathrm{p}<0.0005$; fig 4). Within the observation period thyroid size was normalised in one patient.

One patient developed permanent hypothyroidism 16 months after and another 24 months after the second ${ }^{131}$ I dose. Figure 2 gives thyroid volume data. Both patients had compensated hypothyroidism with serum thyroid stimulating hormone concentrations of 7 and $11 \mathrm{mU} / \mathrm{l}$.

One patient developed hyperthyroidism one month after the initial ${ }^{131} \mathrm{I}$ dose and was treated with antithyroid drugs for 10 months. Thereafter another ${ }^{131} \mathrm{I}$ dose was given and the patient has been euthyroid since. Figure 3 gives thyroid volume data.

One patient received four doses of ${ }^{131} \mathrm{I}(800,555,555$, and $740 \mathrm{MBq}$ ); thyroid volume decreased from $96 \mathrm{ml}$ to $56 \mathrm{ml}$ and the patient has remained euthyroid (fig 4).

During the observation period 11 of 69 patients $(16 \%)$ developed hypothyroidism. Life table analysis showed a risk of hypothyroidism 60 months after treatment of $22 \%$ ( $95 \%$ confidence interval $4 \cdot 8 \%$ to $38 \cdot 4 \%$; fig 5 ).

SIDE EFFECTS

Eleven patients developed hypothyroidism. Three patients developed hyperthyroidism and needed drug treatment; one of these patients required repeat ${ }^{131} \mathrm{I}$

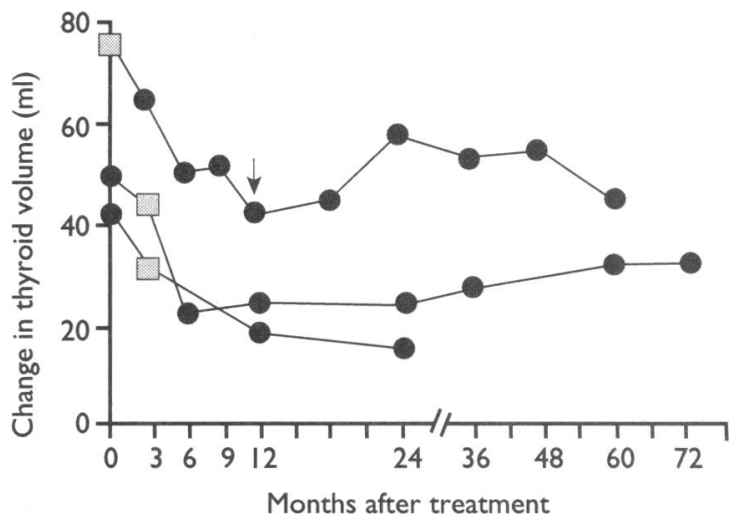

FIG 3-Changes in thyroid volume in three patients developing hyperthyroidism after iodine-131 treatment of non-toxic multinodular goitre. Arrow indicates time of second dose; box indicates diagnosis of hyperthyroidism

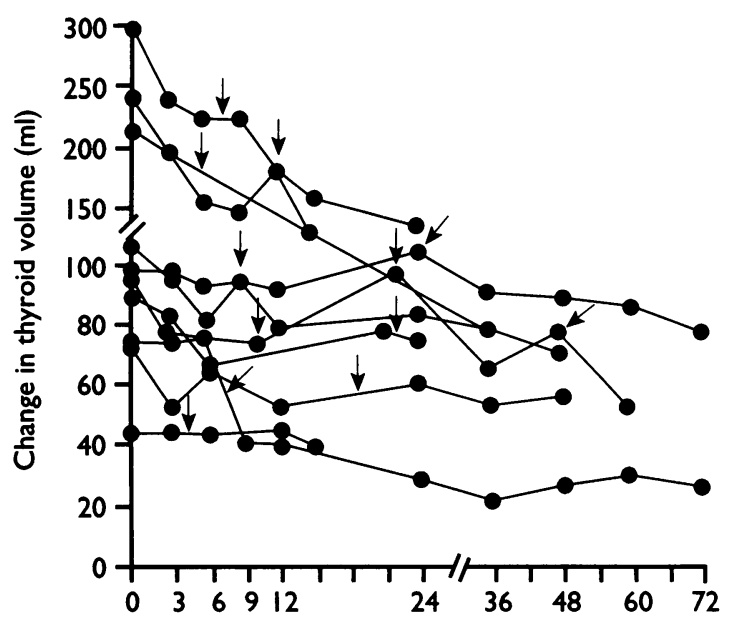

Months after treatment

FIG 4 -Changes in thyroid volume in nine patients remaining euthyroid after two doses and one patient after four doses of iodine-131 for non-toxic multinodular goitre. Arrows indicate times of additional doses 


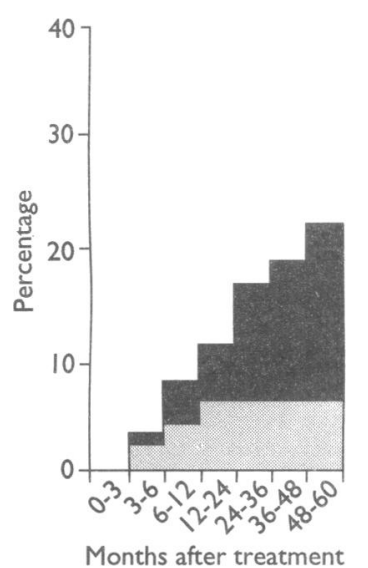

FIG 5-Life table analysis of risk of hypothyroidism during 60 months follow up after treatment of non-toxic goitre with iodine-131. Hatched area indicates risk for patients receiving levothyroxine for decompensated hypothyroidism; solid area indicates risk for patients receiving levothyroxine for compensated hypothyroidism (normal serum thyroxine but raised serum thyrotropin concentrations) treatment; none of these patients developed hypothyroidism. Two patients had a transient ( 8 weeks and 12 weeks) episode of radiation induced thyroiditis characterised by mild thyrotoxicosis and anterior neck tenderness; one needed steroid treatment. None of the five patients with test results showing an increase in thyroid function had an increase in thyroid volume. We encountered no cases of exacerbation of obstructive symptoms, and only one of the patients has been referred for thyroidectomy.

\section{Discussion}

Sporadic and-in countries with relatively low daily iodine intake-endemic goitre is a fairly common condition. In Denmark, where there is a low to borderline iodine intake of 50-80 $\mathrm{gg} / \mathrm{day},{ }^{1314} \mathrm{a}$ minimum of $5 \%$ of the adult population is estimated to have a multinodular non-toxic goitre. ${ }^{10}$ Thyroid suppression with thyroxine or triiodothyronine, effective at least transiently in diffuse non-toxic goitre, ${ }^{2}$ is probably without lasting benefit in multinodular goitre. ${ }^{35}$ Spontaneous reduction in goitre size is unlikely; on the contrary, an average yearly growth rate of up to $20 \%$ is to be expected. ${ }^{1}$ Surgery is effective and rapidly relieves pressure related symptoms, but goitre recurs in at least $10-15 \%$ of patients, ${ }^{56}$ the number depending on definition and length of follow up but probably independent of whether thyroxine is given after operation. ${ }^{5}$ Reoperation for whatever indication increases the probability of complications, particularly hypoparathyroidism and laryngeal nerve damage. ${ }^{15} 16$ The larger the glands the more likely the operative complications. Furthermore, many patients with large multinodular goitres are elderly, and surgery may be contraindicated by other medical conditions. Additionally, a number of patients refuse to be operated on. In this light we sought to evaluate the long term outcome of ${ }^{131}$ I treatment for non-toxic multinodular goitre.

\section{EFFECT ON THYROID VOLUME}

This longitudinal prospective long term study comprising 69 patients showed an overall decrease of $34 \%$ in ultrasonically determined thyroid volume after ${ }^{131} \mathrm{I}$ treatment after 12 months and $55 \%$ after 24 months. As the expected spontaneous growth rate is $10-20 \%$ a year, ${ }^{1}$ the reduction could well be even more pronounced. Most patients were treated with one dose of ${ }^{131} \mathrm{I}$, and half of the achievable thyroid volume reduction of $60 \%$ (at 24 months) occurred within three months of treatment. Patients offered repeat treatment showed a reduction in volume after the first ${ }^{131} \mathrm{I}$ dose; a second dose was generally given when the initial volume reduction was inadequate, mostly in patients in whom the first dose was lower than intended due to large glands or a low uptake of ${ }^{131} \mathrm{I}$. Patients with

\begin{tabular}{l} 
Clinical implications \\
\hline - The incidence of non-toxic multinodular \\
goitre increases with age \\
- Some patients do not wish operation or are \\
poor candidates for surgery \\
- Radioiodine is well tolerated as an outpatient \\
procedure and can be repeated \\
- A $30 \%$ reduction in thyroid volume can be \\
achieved within three months and a $50-60 \%$ \\
reduction within 24 months \\
- Side effects are few and the five year risk of \\
hypothyroidism is $22 \%$ \\
\hline
\end{tabular}

thyroiditis and hyperthyroidism did not have an increase in thyroid volume. Generally the reduction was of the same order in these patients as that seen after ${ }^{131}$ I treatment in toxic multinodular goitre. ${ }^{7}$ Other researchers who have shown reductions in goitre size after ${ }^{131}$ I treatment in patients with multinodular goitre have used less accurate methods (palpation, neck circumference, and scintigraphy) and scantier observations. ${ }^{17-20}$

Although 10 of the 59 patients had a small increase in thyroid volume within the first month this in no case caused an exacerbation of obstructive or other symptoms. Surprisingly, 20 patients had normal or only slightly increased thyroid volume $(<50 \mathrm{ml})$ before treatment, but this is in part explained by recurrence of a unilateral symptomatic goitre in patients with a previous hemithyroidectomy. The average reduction in thyroid volume was independent of initial size of the thyroid. This is not surprising since the dose of ${ }^{131} \mathrm{I}$ was adjusted for thyroid size.

\section{SIDE EFFECTS}

The cumulative risk of hypothyroidism five years after ${ }^{131} \mathrm{I}$ treatment was $22 \%$, very different from the risk of $100 \%$ after eight years observed by Verelst $e t a l^{20}$ and the $1.6 \%$ found by Keiderling et al. ${ }^{17}$ These differences and the lack of a relation between ${ }^{131}$ I dose and subsequent development of hypothyroidism in the present study suggests that the individual sensitivity to ${ }^{131}$ I governs the subsequent development of hypothyroidism. In the present study the risk of hypothyroidism was probably overestimated since all patients receiving levothyroxine were classified as hypothyroid although seven of 11 patients had compensated hypothyroidism. It is well accepted that this condition can be stable for several years before possible progression to manifest hypothyroidism. The risk of hypothyroidism is clearly lower than that reported for Graves' disease and not higher than that reported for nodular toxic goitre. ${ }^{21}$ Since the main purpose of ${ }^{131} \mathrm{I}$ treatment is to decrease nodular volume the accompanying low incidence of hypothyroidism cannot be classified as a serious side effect. Higher ${ }^{131} \mathrm{I}$ doses might even be contemplated. Since there is evidence of a subtle ongoing reduction in thyroidal secretion in patients remaining clinically euthyroid these patients should be offered prolonged follow up in case of possible late hypothyroidism..$^{22}$

Side effects were few and especially no clinically detectable increase in goitre size or exacerbation of obstructive symptoms were noted. The results were satisfactory, except in one patient with a small goitre $(30 \mathrm{ml})$ who wished to be referred for surgery six months after treatment. Three patients developed features of hyperthyroidism one to three months after ${ }^{131}$ I therapy and needed drug treatment. The possibility of one or more of these patients having Graves' disease cannot be excluded. A similar case was described by Kay et al. ${ }^{19}$ Another two patients had a transient episode of radiation induced thyroiditis and mild thyrotoxicosis. Present evidence does not suggest an increased risk of thyroid malignancy or leukaemia after therapeutic doses of ${ }^{131} \mathrm{I}^{2324}$ and there seem to be only emotional reasons for limiting this treatment to highly selected patients.

\section{CONCLUSION}

A substantial reduction in nodular thyroid volume accompanied by a low incidence of hypothyroidism justifies the use of ${ }^{131} \mathrm{I}$, especially for recurrence of multinodular non-toxic goitre after surgery or in patients who may have contraindications to surgery. This treatment could be more widely used.

This study was supported by a grant from the Agnes and 
Knut Morks Foundation. These results were presented in part at the 21st annual meeting of the European Thyroid Association, Cardiff, 4-9 July 1993 and abstracted in f Endocrinol Invest 1993;16(suppl 2):81.

1 Berghout A, Wiersinga WM, Drexhage HA, Smits NJ, Touber JL. Comparison of placebo with L-thyroxine alone or with carbimazole for treatment of sporadic non-toxic goitre. Lancet 1990;336:193-7.

2 Perrild $\mathrm{H}$, Hansen JM, Hegedüs L. Triiodothyronine and thyroxine treatment of diffuse non-toxic goitre evaluated by ultrasonic scanning. Acta Endocrinol (Copenh) 1982;100:382-7.

3 Gharib H, James EM, Charboneau JW, Naessens JM, Offord KP, Gorman CA. Suppressive therapy with levothyroxine for solitary thyroid nodules. A double-blind controlled clinical study. N Engl f Med 1987;317:70-5.

4 Hegedüs L, Hansen JM, Veiergang D, Karstrup S. Does prophylactic thyroxine treatment after operation for non-toxic goitre influence thyroid size? BMF 1987;294:801-3.

5 Hegedüs L, Hansen JM, Hansen BM, Hjalgrim H, Gervil M. Is prophylactic thyroxine therapy after operation for non-toxic goitre justified? [abstract] Thyroid 1991;1(suppl 1):2.

6 Geerdsen JP, Frolund L. Recurrence of non-toxic goitre with and without postoperative thyroxine medication. Clin Endocrinol (Oxf) 1984;21:529-33. Hegedüs L Hansen JM. Radioactive iodine for thyrotoxicosis. Lance 1986;ii:339-40,876.

8 Hegedüs L, Veiergang D, Karstrup S, Hansen JM. Compensated 'iI-therapy of solitary autonomous thyroid nodules: effect on thyroid size and early of solitary autonomous thyroid nodules: effect on thyroid si

9 Hegedüs I Hansen BM, Knudsen N, Hansen JM. Reduction of size of thyroid with radioactive iodine in multinodular non-toxic goitre. $B M F$ 1988:297:661-2.

10 Hegedüs L, Perrild H, Poulsen LR, Andersen IP, Holm B, Schnohr P, et al. Determination of thyroid volume by ultrasound and its relationship to body weight, age and sex in normal subjects. F Clin Endocrinol Metab 1983;56: 260-3.

11 Hegedũs L, Karstrup S, Rasmussen N. Evidence of cyclic alterations of thyroid size during the menstrual cycle in healthy women. $A m \mathcal{J}$ Obstet Gynecol 1986;155:142-5.
12 Hollander M, Wolfe DA. Non-parametric statistical methods. New York: Wiley, 1973:147-50,372.

13 Hansen JM, Skovsted L, Siersbrek-Nielsen K. Age dependent changes in iodine metabolism and thyroid function. Acta Endocrinol (Copenh) 1975;79: 60-5.

14 Haas V, Marley M, Green A, Date J, Blichert-Toft M, Mogensen E. Urinary iodine excretion in a geographically stratified Danish population sample not effected by iodination programmes. Acta Endocrinol (Copenh) 1988;119:125 31.

15 Beahrs OH, Vandertoll DJ. Complications of secondary thyroidectomy. Surg Gynaecol Obstet 1963;17:535-9.

16 Agerbak H, Pilegaard HK, Watt-Boolsen S, Spangberg N, Madsen MR, Laursen CN, et al. Komplikationer ved 2.028 operationer for benign thyreoideasygdom. Ugeskrift for Lager 1988;150:533-6.

17 Keiderling W, Emrich D, Hanzwaldi C, Hoffman G. Ergebnisse der Radiojodverkleinerungstherapie euthyreoter Strumen. Dtsch Med Wochenschr 1964;89:453-7.

18 Klein B, Klein E, Horster FA. Ergebnisse der fraktionierten Radiojodtherapie bei 696 Hyperthyreosen und 690 blanden Strumen. Nucl Med 1989;28:129-

19 Kay TWH, d'Emden MC, Andrews JT, Martin FIR. Treatment of non-toxic multinodular goiter with radioactive iodine. Am f Med 1988;84:19-22.

20 Verelst J, Bonnyns M, Glinoer D. Radioiodine therapy in voluminous multinodular non-toxic goitre. Acta Endocrinol (Copenh) 1990;122:417-21.

21 Farrar J, Toft AD. Iodine 131 treatment of hyperthyroidism: current issues. Clin Endocrinol (Oxf) 1991;35:207-12.

22 Jarlov AE, Faber J, Hegedüs L, Hansen JM. Subtle changes in serum thyrotropin (TSH) and sex-hormone-binding globulin (SHBG) levels during long term follow up after radioactive iodine in multinodular nontoxic goitre. Clin Endocrinol (Oxf) 1992;37:335-7.

23 Holm L-E, Hall P, Wiklund K, Lundell G, Berg G, Bjelkengren G, et al. Cancer risk after iodine 131 therapy for hyperthyroidism. I Natl Cancer Inst 1991;83:1072-7.

24 Hall P, Boice JD Jr, Berg G, Bjelkengren G, Ericsson U-B, Hallqvist A, et al. Leukaemia incidence after iodine 131 exposure. Lancet 1992;340:1-4.

(Accepted 12 August 1993)
Department of Cardiology, Royal Victoria Infirmary, Newcastle upon Tyne NE1 4LP

M Farrer, Wellcome junior

clinical research fellow

C J Albers, research

coordinator

P C Adams, consultant

cardiologist

Department of Clinical

Biochemistry, University of

Newcastle upon Tyne,

Newcastle upon Tyne

NE1 4HH

F L Game, Medical Research

Council trainee

M F Laker, reader

Department of Public

Health and Primary Care,

University of Oxford,

Oxford OX2 6HE

$\mathrm{H}$ A W Neil, lecturer and

honorary consultant

Department of Medicine,

University of Newcastle

upon Tyne, Newcastle

upon Tyne NE1 4HH

P H Winocour, senior

registrar

K G M M Alberti, professor of

medicine

Correspondence to:

Dr M Farrer, Cardiothoracic

Centre, Freeman Hospital,

Newcastle upon Tyne

NE7 7DN.

BMF 1993;307:832-6

\title{
Association between impaired glucose tolerance and circulating concentration of $\mathrm{Lp}(\mathrm{a})$ lipoprotein in relation to coronary heart disease
}

\author{
M Farrer, F L Game, C J Albers, H A W Neil, P H Winocour, M F Laker, P C Adams, \\ K G M M Alberti
}

\section{Abstract}

Objective-To examine whether impaired glucose tolerance and raised $L p(a)$ lipoprotein concentrations are associated in subjects with coronary artery disease.

Design-Study of two subject populations, one with and one without symptomatic coronary artery disease. Case-control analysis of patients with impaired glucose tolerance and normal glucose tolerance performed in each subject population independently.

Setting - A general practice and a hospital ward in Newcastle upon Tyne.

Subjects-517 apparently healthy subjects, 13 with impaired glucose tolerance, and 245 patients who had undergone coronary artery bypass graft surgery 12 months before, 51 with impaired glucose tolerance.

Main outcome measures-Serum Lp(a) lipoprotein concentration, plasma glucose concentration before and after oral challenge with $75 \mathrm{~g}$ glucose monohydrate, and $\mathrm{Lp}$ (a) lipoprotein isoforms.

Results-In both the asymptomatic subjects and the subjects with coronary artery disease there was no significant difference between subjects with impaired glucose tolerance and subjects with normal glucose tolerance who were matched for age, sex, and body mass index in serum $\mathrm{Lp}$ (a) lipoprotein concentrations (geometric mean 61 (geometric SD 4) $\mathrm{mg} / \mathrm{l} 83$ (5) $\mathrm{mg} / \mathrm{l}$ for asymptomatic subjects, 175 (3) $v 197$ (2) for subjects with heart disease), nor was there any difference in the proportion of subjects who had Lp(a) lipoprotein concentrations $>300 \mathrm{mg} / \mathrm{I}$ $(31 \% v 23 \%$ for asymptomatic subjects, $37 \% v 37 \%$ for subjects with heart disease). For both subject groups there was no significant correlation between Lp(a) lipoprotein concentration and plasma glucose concentration after a glucose tolerance test, nor did Lp(a) lipoprotein concentration vary by quintile of glucose concentration after the test. Examination of Lp(a) lipoprotein isoforms in the subjects with coronary artery disease revealed an inverse relation between isoform size and plasma $\operatorname{Lp}(a)$ lipoprotein concentration, but there was no evidence that impaired glucose tolerance was associated with particular $\mathbf{L p}$ (a) lipoprotein isoforms.

Conclusion-Raised Lp(a) lipoprotein concentrations are not responsible for the association between impaired glucose tolerance and coronary artery disease.

\section{Introduction}

Impaired glucose tolerance has been associated with an approximate doubling in the risk of ischaemic heart disease in studies performed in the United Kingdom. ${ }^{12}$ High circulating $\mathrm{Lp}$ (a) lipoprotein concentrations have also been associated with an increased risk of ischaemic heart disease. ${ }^{3-13} \mathrm{~A}$ study of people with no evidence of ischaemic heart disease suggested a fivefold increase in the prevalence of raised lipoprotein(a) concentrations $(>300 \mathrm{mg} / \mathrm{l}$ ) in those with impaired glucose tolerance compared with those with normal glucose tolerance. ${ }^{14}$ It was proposed that a high concentration of lipoprotein(a) may explain the increased risk of ischaemic heart disease in people with impaired glucose tolerance. To investigate this we examined the relation between glucose tolerance and circulating lipoprotein(a) 